\title{
Atmospheric science: the self-cleansing ability of prehistoric air
}

Article

Accepted Version

Hegglin, M. I. (2017) Atmospheric science: the self-cleansing ability of prehistoric air. Nature, 546 (7656). pp. 41-43. ISSN 0028-0836 doi: https://doi.org/10.1038/546041a Available at https://centaur.reading.ac.uk/70876/

It is advisable to refer to the publisher's version if you intend to cite from the work. See Guidance on citing.

To link to this article DOI: http://dx.doi.org/10.1038/546041a

Publisher: Nature Publishing Group

All outputs in CentAUR are protected by Intellectual Property Rights law, including copyright law. Copyright and IPR is retained by the creators or other copyright holders. Terms and conditions for use of this material are defined in the End User Agreement.

\section{www.reading.ac.uk/centaur}

\section{CentAUR}

Central Archive at the University of Reading

Reading's research outputs online 
Atmospheric science

Prehistoric air's self-cleansing ability

Isotopic data from an ice core have been used to estimate atmospheric oxidant levels during past climate transitions - pointing to relatively unexplored climate feedbacks as drivers of atmospheric composition. See Letter p.XXX

Michaela I. Hegglin

The atmosphere has a self-cleansing ability ${ }^{1}$ that stops certain air pollutants and greenhouse gases from accumulating, thus preventing catastrophic consequences for air quality and climate, respectively ${ }^{2}$. The rate of self-cleansing — known as the oxidation capacity - determines the lifetime of such pollutants and gases, and depends on the abundance of oxidants in the troposphere, the lowest layer of the atmosphere. It would be useful to know how tropospheric oxidant levels varied during past periods of climate change, to inform models used to predict future climate, but such information has been conspicuously absent. On page XXX, Geng et $a l .^{3}$ present a promising proxy data set for such oxidants during the most recent glacial-interglacial cycle, based on an isotopic quantity known as the oxygen-17 excess of nitrate, $\Delta^{17} \mathrm{O}\left(\mathrm{NO}_{3}{ }^{-}\right)$.

The primary oxidant in the atmosphere is the hydroxyl radical $(\mathrm{OH})$, which is generated by photochemical processes involving water vapour, ozone and 
ultraviolet radiation (Fig. 1). Because $\mathrm{OH}$ has a short lifetime of just a few seconds (ref. 2), its atmospheric concentration is highly variable and difficult to measure. Researchers have therefore developed techniques that allow atmospheric $\mathrm{OH}$ levels to be quantified indirectly by measuring concentrations of trace gases ${ }^{4}$ whose lifetimes are much longer and depend on $\mathrm{OH}$ abundances.

Inferring the abundance of tropospheric oxidants is even more challenging when trying to look into the past. Long-lived trace gases can be analysed readily from air trapped in ice cores, but short-lived species cannot, because they are too reactive to be preserved. This has led to a lack of information on past oxidant levels.

To address this problem, Geng et al. collected $\left.\Delta^{17} \mathrm{O}_{\left(\mathrm{NO}_{3}\right.}{ }^{-}\right)$data from a Greenland ice core that preserves a record of the most recent glacial-interglacial cycle (the past 100,000 years). $\Delta^{17} \mathrm{O}\left(\mathrm{NO}_{3}{ }^{-}\right)$had previously been suggested ${ }^{5}$ to be a valuable proxy for the tropospheric oxidation capacity - more specifically, for the ratio of the concentration of ozone $\left(\mathrm{O}_{3}\right)$ to that of $\mathrm{HO}_{\mathrm{x}}$ (the group of atmospheric compounds that includes $\mathrm{OH}$ and other oxidants called peroxy radicals). If the longterm evolution of $\mathrm{O}_{3} / \mathrm{HO}_{\mathrm{x}}$ is known, feedbacks between atmospheric chemistry and climate can be investigated.

The $\mathrm{O}_{3} / \mathrm{HO}_{\mathrm{x}}$ ratio was previously believed to be directly proportional to temperature, because emissions of ozone precursors from biological sources are expected to increase as climate warms ${ }^{6,7}$. Geng and colleagues' proxy data set 
surprisingly reveals an inverse relationship between $\mathrm{O}_{3} / \mathrm{HO}_{\mathrm{x}}$ and temperature, both at glacial-to-interglacial timescales and during a Dansgaard-Oeschger event (an episode characterized by rapid warming over a few decades, followed by gradual cooling over hundreds to thousands of years). Puzzlingly, however, the authors observed that $\mathrm{O}_{3} / \mathrm{HO}_{\mathrm{x}}$ was, in fact, directly proportional to temperature during another Dansgaard-Oeschger event characterized by a moderately warmer cooling period.

To interpret their results, the authors used a modelling framework that simulates the effects of climate and of the biosphere on tropospheric chemistry. On this basis, they infer that the primary factors responsible for the changes in oxidant levels were the chemistry of halogen-containing compounds in the atmosphere and transport of ozone from the stratosphere to the troposphere. Those inferences are certainly plausible, but have to be regarded as speculative given the limitations of their modelling framework.

Climate models that simulate interactions between atmospheric chemistry and climate, and which include a well-resolved stratosphere, have indeed shown that stratosphere-to-troposphere transport of ozone increases under a warming climate ${ }^{7,8}$. But the impact of the simulated transport changes on tropospheric ozone depends strongly on the region involved, and can lead locally to either increases or decreases of ozone levels ${ }^{8}$. These models have not yet been used to study stratosphere-to-troposphere transport in past colder climates. They also generally 
do not incorporate the complex halogen chemistry invoked by Geng et al.; when this chemistry is added to the basic tropospheric chemistry typically used in models, tropospheric ozone levels can reduce significantly in simulations of modern conditions ${ }^{9}$. All things considered, Geng and colleagues' proposal is probably the best current hypothesis to explain the observed changes of oxidant levels.

The new results highlight once again how little we understand about the complexity of chemistry-climate feedbacks, and more generally of how strongly Earth-system processes are interconnected. Tropospheric composition is driven in different ways by the ocean, cryosphere (the part of the Earth system that is frozen water), lithosphere (Earth's rocky, outermost shell), and the land and marine biospheres, but also by the stratosphere. It will be crucial to develop a better understanding of the feedback mechanisms to more accurately predict how anthropogenic emissions might affect climate and air quality in the future. In particular, a deeper understanding of how atmospheric composition - especially the lifetime of greenhouse gases - is affected by climate change will be important when interpreting information from climate models to make policy decisions about how to limit global warming below certain temperature targets.

A new generation of Earth-system models that encompass all of the processes and feedbacks that determine climate - including those associated with the stratosphere - will be needed to answer questions of how atmospheric composition and climate interact. Simulations should not simply be 'tuned' to 
provide the best reproduction of present climate, but should be built on an understanding of the processes involved, to allow the credible simulation of both past and present climates. Most crucially, these models should be compared continuously with observations and proxy palaeoclimate data, to test their validity and to inform further development. This in turn will require strong collaborations between modellers and data-collecting scientists, and will need palaeoclimate researchers to join their expertise with that of experts studying present and future climate.

Michaela I. Hegglin is in the Department of Meteorology, University of Reading, Reading RG6 6BX, UK.

e-mail: m.i.hegglin@reading.ac.uk

${ }^{1}$ Prinn, Ronald G. The cleansing capacity of the atmosphere. Annual Review of Environment and Resources 28.1, 29-57, 2003.

${ }^{2}$ Lelieveld, J., W. Peters, F. J. Dentener, and M. C. Krol, Stability of tropospheric hydroxyl chemistry. J. Geophys. Res. 107(D23), 4715, doi:10.1029/2002JD002272, 2002.

${ }^{3}$ Geng et al. Nature XXX, XXX-XXX (2017).

${ }^{4}$ Montzka, S., Krol, M., Dlugokencky, E., Hall, B., Jöckel, P., \& Lelieveld, J. Small Interannual Variability of Global Atmospheric Hydroxyl. Science, 331(6013), 67-69. Retrieved from http://www-jstor-org.idpproxy.reading.ac.uk/stable/40986633, 2011. 
${ }^{5}$ Alexander, B. \& Mickley, L. Paleo-Perspectives on Potential Future Changes in the Oxidative Capacity of the Atmosphere Due to Climate Change and Anthropogenic Emissions. Curr. Pollution Rep., 1-13, doi:10.1007/s40726-015-0006-0, 2015. ${ }^{6}$ Murray, L. T. et al. Factors controlling variability in the oxidative capacity of the troposphere since the Last Glacial Maximum. Atmos. Chem. Phys. 14, 3589-3622, doi:10.5194/acp-14-3589-2014, 2014.

${ }^{7}$ Peñuelas, J. and M. Staudt. BVOCs and global change. Trends in plant science, 15(3), 133-144, 2010.

${ }^{8}$ Hegglin, M. I., and T. G. Shepherd. Large climate-induced changes in UV index and stratosphere-to-troposphere ozone flux. Nature Geoscience 2, 687-691, 2009.

${ }^{9}$ Zeng, G., O. Morgenstern, P. Braesicke, and J. A. Pyle. Impact of stratospheric ozone recovery on tropospheric ozone and its budget. Geophys. Res. Lett., 37, L09805, doi:10.1029/2010GL042812, 2010.

${ }^{10}$ Schmidt, J. A., et al. Modeling the observed tropospheric BrO background: Importance of multiphase chemistry and implications for ozone, $\mathrm{OH}$, and mercury, $\mathrm{J}$. Geophys. Res. Atmos. 121, 11,819-11,835, doi:10.1002/2015JD024229, 2016.

Figure 1 | Factors influencing the self-cleansing ability of the troposphere. The atmosphere has a 'self-cleansing' ability that depends on the abundance of oxidants in the troposphere, the lowest layer of the atmosphere - particularly the abundance of the hydroxyl radical $(\mathrm{OH})$. The primary production of $\mathrm{OH}$ depends on the availability of ozone $\left(\mathrm{O}_{3}\right.$, part of which is generated in the stratosphere and transported to the troposphere), water vapour and ultraviolet light. Secondary 
processes recycle $\mathrm{OH}$ in reactions driven by emissions of nitrogen oxides $\left(\mathrm{NO}_{\mathrm{x}}\right)$, carbon monoxide (CO) and volatile organic compounds (VOCs) from anthropogenic and biological sources. Halogen radicals produced in sea spray tend to decrease $\mathrm{OH}$ levels. The relative contributions of the different processes to the overall $\mathrm{OH}$ budget are expected to change as climate changes. Geng et al. ${ }^{3}$ report isotopic measurements that act as a proxy for tropospheric oxidant levels during the most recent glacial-interglacial transition, and argue that the main influencing factors were the chemistry of halogen radicals and stratosphere-to-troposphere transport of ozone. 